\title{
Article \\ Production of Chlorella vulgaris Biomass in Tubular Photobioreactors during Different Culture Conditions
}

\author{
Patryk Ratomski (D) and Małgorzata Hawrot-Paw * (D) \\ Department of Renewable Energy Engineering, West Pomeranian University of Technology in Szczecin, \\ Pawla VI 1, 71-459 Szczecin, Poland; patryk.ratomski@zut.edu.pl \\ * Correspondence: Malgorzata.hawrot-paw@zut.edu.pl
}

check for updates

Citation: Ratomski, P.; Hawrot-Paw, M. Production of Chlorella vulgaris Biomass in Tubular Photobioreactors during Different Culture Conditions. Appl. Sci. 2021, 11, 3106. https:// doi.org/10.3390/app11073106

Academic Editors: Birthe Vejby Nielsen and George Aggelis

Received: 23 January 2021

Accepted: 25 March 2021

Published: 31 March 2021

Publisher's Note: MDPI stays neutral with regard to jurisdictional claims in published maps and institutional affiliations.

Copyright: (c) 2021 by the authors. Licensee MDPI, Basel, Switzerland. This article is an open access article distributed under the terms and conditions of the Creative Commons Attribution (CC BY) license (https:// creativecommons.org/licenses/by/ $4.0 /)$
Abstract: Biomass of microalgae and the components contained in their cells can be used for the production of heat, electricity, and biofuels. The aim of the presented study was to determine the optimal conditions that will be the most favorable for the production of large amounts of microalgae biomass intended for energy purposes. The study analyzed the effect of the type of lighting, the time of lighting culture, and the $\mathrm{pH}$ of the culture medium on the growth of Chlorella vulgaris biomass. The experiment was carried out in vertical tube photobioreactors in three photoperiods: 12/12, 18/6, and 24/0 h (light/dark). Two types of lighting were used in the work: high-pressure sodium light and light-emitting diode. The increase in biomass was determined by the gravimetric method, by the spectrophotometric method on the basis of chlorophyll a contained in the microalgae cells. The number of microalgae cells was also determined with the use of a hemocytometer. The optimal conditions for the production of biomass were recorded at a neutral $\mathrm{pH}$, illuminating the cultures for $18 \mathrm{~h}$ a day. The obtained results were $546 \pm 7.88 \mathrm{mg} \cdot \mathrm{L}^{-1}$ dry weight under sodium lighting and $543 \pm 1.92 \mathrm{mg} \cdot \mathrm{L}^{-1}$ dry weight under light-emitting diode, with maximum biomass productivity of $27.08 \pm 7.80$ and $25.00 \pm 5.1 \mathrm{mg} \cdot \mathrm{L}^{-1} \cdot \mathrm{d}^{-1}$, respectively. The maximum content of chlorophyll a in cells was determined in the $12 / 12 \mathrm{~h}$ cycle and $\mathrm{pH} 6\left(136 \pm 14.13 \mathrm{mg} \cdot \mathrm{m}^{-3}\right)$ under light-emitting diode and $18 / 6 \mathrm{~h}$, pH $7\left(135 \pm 6.17 \mathrm{mg} \cdot \mathrm{m}^{-3}\right)$ under sodium light, with maximum productivity of $26.34 \pm 2.01 \mathrm{mg} \cdot \mathrm{m}^{-3} \cdot \mathrm{d}^{-1}$ (light-emitting diode) and $24.21 \pm 8.89 \mathrm{mg} \cdot \mathrm{m}^{-3} \cdot \mathrm{d}^{-1}$ (sodium light). The largest number of microalgae cells $\left(2.1 \times 10^{6}\right)$ was obtained at $\mathrm{pH} 7$ and photoperiod of $18 / 6 \mathrm{~h}$ under sodium light, and 12/12 h under light-emitting diode. Based on the results, it can be concluded that the determination of the optimal parameters for the growth and development of microalgae determines the production of their biomass, and such research should be carried out before starting the large-scale production process. In quantifying the biomass during cultivation, it is advantageous to use direct measurement methods.

Keywords: photobioreactor; microalgal biomass; algae cultivation conditions; optimization

\section{Introduction}

Microalgae are among the most widespread organisms. According to Guiry [1], it is estimated that there are up to 1 million species of algae on Earth. We meet them in the entire biosphere, but above all in fresh, salt, and saline waters. A characteristic feature of algae is the presence of chlorophyll [2,3], which enables photosynthesis to be carried out in each individual cell [4]. The efficiency of this process and the related biomass production is much higher compared to land plants [5].

Microalgae biomass has been widely used in various industries: pharmaceutical, food, animal feed, water purification, and biofuel production [6-8]. Under suitable conditions, microalgae convert solar energy into chemical energy of compounds accumulated in their cells, including not only in carbohydrates and proteins but also in lipids, which are used in the production of biodiesel $[9,10]$. The biomass yield and the biochemical composition of microalgae depend on environmental and physiological factors such as culture temperature, $\mathrm{pH}$, lighting intensity and type, availability of nutrients, and carbon dioxide [11]. 
Lighting directly influences the growth of microalgae through photosynthesis. Algae cells, like most organisms, require not only access to light but also the dark phase, where photochemical processes occur and both ATP and NADPH are formed in algae cells [12]. Research on determining the optimal photoperiod in microalgae cultivation indicates that the efficiency of algal biomass production increases with the lengthening of the light to dark ratio $[12,13]$. When selecting the optimal light, the quality of the spectrum and the light intensity must be taken into account. The quality of the spectrum is defined by the absorption spectrum of chlorophyll and other components present in algae cells, which include phycobilins and carotenoids. The energy consumption of algae cells depends on the chemical conditions of the constitutive pigments [14]. The assimilation pigments have two main bands of blue-green light absorption with a wavelength of 450-475 nm and red light, 630-675 nm [15]. Lighting should be evenly distributed throughout the reactor allowing the photons to reach the cells. Excessive light intensity can lead to photooxidation and photoinhibition, while low light levels will reduce the growth of microalgae [16].

The $\mathrm{pH}$ of a culture medium not only affects the composition and lifetime of microalgae cells but also determines the availability of nutrients, the proper course of the photosynthesis process, and the uptake of carbon dioxide by cells [17]. The acidic conditions adversely affect the absorption of nutrients and disrupt the functioning of microalgae cells, while alkaline conditions reduce the ability to assimilate carbon dioxide. Research indicates that for most microalgae, the optimal pH range is between 6 and 10 [18]. Optimization of cultivation conditions is crucial for industrial productivity of microalgae. The objective aim of this work was to analyze some of the parameters important for algal biomass production and methods suitable for estimating Chlorella vulgaris growth. In this study, we hypothesized that optimization of basic culture conditions leads to higher biomass concentration in the photobioreactors.

\section{Materials and Methods}

\subsection{Material}

Chlorella vulgaris microalgae (BA 002) were used in this research. The material was obtained from Culture Collection of Baltic Algae (CCBA) (University of Gdansk, Gdańsk, Poland).

\subsection{Experimental Setup}

The experiment was carried out in vertical tubular photobioreactors (Aqua Medic, Bissendorf, Germany) with a capacity of $2.5 \mathrm{dm}^{3}$ (Figure 1), supplemented with $2 \mathrm{dm}^{3}$ of the F/2 culture medium [19] with the composition (g/L): $\mathrm{NaNO}_{3}-0.075 \mathrm{~g} ; \mathrm{NaH}_{2} \mathrm{PO}_{4} \cdot 2 \mathrm{H}_{2} \mathrm{O}-0.00565 \mathrm{~g}$; stock solution of trace elements- $1 \mathrm{~mL} / \mathrm{L}\left(\mathrm{Na}_{2}\right.$ EDTA $4.16 \mathrm{~g}$, $\mathrm{FeCl}_{3} 6 \mathrm{H}_{2} \mathrm{O} 3.15 \mathrm{~g}, \mathrm{CuSO}_{4} 5 \mathrm{H}_{2} \mathrm{O}$ $0.01 \mathrm{~g}, \mathrm{ZnSO}_{4} 7 \mathrm{H}_{2} \mathrm{O} 0.022 \mathrm{~g}, \mathrm{CoCl}_{2} 6 \mathrm{H}_{2} \mathrm{O} 0.01 \mathrm{~g}, \mathrm{MnCl}_{2} 4 \mathrm{H}_{2} \mathrm{O} 0.18 \mathrm{~g}$, and $\mathrm{NaMoO}_{4} 2 \mathrm{H}_{2} \mathrm{O} 0.18 \mathrm{~g}$ ) and stock solution of vitamin mix $-1 \mathrm{~mL} / \mathrm{L}$ (cyanocobalamin (vitamin B12) $0.0005 \mathrm{~g}$, thiamine $\mathrm{HCl}$ (vitamin B1) $0.1 \mathrm{~g}$, biotin $0.0005 \mathrm{~g}$ ). After sterilization of the medium with $\mathrm{UV}$ light, $200 \mathrm{~cm}^{3}$ of $C$. vulgaris microalgae inoculum was introduced into the photobioreactors.

In the study, we analyzed the effect of two types of lighting: high-pressure sodium light (HPS-Son-T-Agro, 400 watt, light intensity of $660 \mu \mathrm{mol} \cdot \mathrm{s}^{-1} / 56,000$ lux; PHILIPS, Amsterdam, Netherlands) and light-emitting diode (LED light with white diodes, red diodes (wavelength 600-700 nm, light intensity of $9.45 \mu \mathrm{mol} \cdot \mathrm{s}^{-1}$ ) and blue diodes (wavelength $400-500 \mathrm{~nm}$, light intensity of $\left.2.25 \mu \mathrm{mol} \cdot \mathrm{s}^{-1}\right)$. Total LED light intensity was $13.5 \mu \mathrm{mol} \cdot \mathrm{s}^{-1}$ (HOLDBOX, Żabia Wola, Poland). Three times of lighting culture were used: 12/12, 18/6, and 24/0 $\mathrm{h}$ in the light/dark cycle and four $\mathrm{pH}$ levels were used: 6, 7, 8, and 9.

Algae cells were kept suspended by mixing with gas using a $25 \mathrm{~W}$ pump (Aqua Medic, Bissendorf, Germany) with a capacity of $0.9 \mathrm{~m}^{-3} \cdot \mathrm{h}^{-1}$. At the same time, the aeration made it possible to introduce carbon dioxide into the culture. The experiment was carried out as a batch culture. To establish an adequately fast and accurate method for the quantification of microalgae biomass, three comparative methods were used: biomass dry 
weight, measuring the content of chlorophyll a, and counting the number of cells using a hemocytometer.

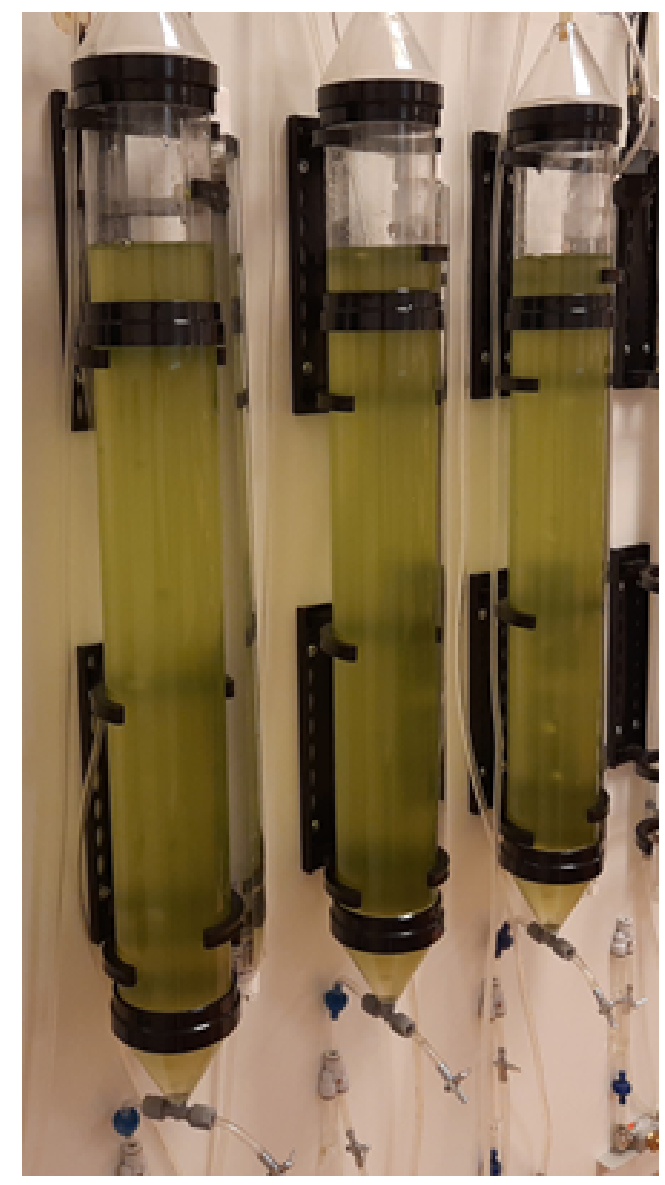

Figure 1. Vertical tubular photobioreactors used in the research.

The dry weight of microalgae has been determined by the gravimetric method described by Ratha et al. [20] with modification. Biomass estimation was carried out using a moisture analyzer (AXIS ATS, Gdańsk, Poland). Aliquots of $40 \mathrm{~cm}^{3}$ were centrifuged (Eppendorf, Hamburg, Germany) at $4000 \times g$ for $15 \mathrm{~min}$. The biomass after centrifugation was transferred to aluminum plates, dried at $105^{\circ} \mathrm{C}$ to constant weight, cooled, and weighed. The results were calculated and presented in $\mathrm{mg} \cdot \mathrm{L}^{-1}$. The amount of biomass was determined on the day the culture was established and at 24-h intervals for the next 15 days. The biomass productivity was calculated by the following equation

$$
\mathrm{BP}=\frac{\mathrm{B}_{\mathrm{f}}-\mathrm{B}_{0}}{\mathrm{~d}},
$$

where $\mathrm{BP}$ is the biomass productivity $\left(\mathrm{mg} \cdot \mathrm{L}^{-1} \cdot \mathrm{d}^{-1}\right), \mathrm{B}_{\mathrm{f}}$ and $\mathrm{B}_{0}$ are final and initial biomass concentration (mg), respectively, and $\mathrm{d}$ is the cultivation time (day).

Chlorophyll concentration was determined according to the PN-86 C-05560/02 standard [21]. The pigment was extracted from biomass concentrated by filtration on a glass fiber filter using 90\% $(v / v)$ acetone. The absorbance of acetone extract was measured at wavelength of $665 \mathrm{~nm}$, with a spectrophotometer (EMCO, Warszawa, Poland). The results are given in $\mathrm{mg} \mathrm{m}^{-3}$. The chlorophyll productivity was calculated using following equation:

$$
\mathrm{ChP}=\frac{\mathrm{Ch}_{\mathrm{f}}-\mathrm{Ch}_{0}}{\mathrm{~d}}
$$


where $\mathrm{ChP}$ is chlorophyll productivity $\left(\mathrm{mg} \cdot \mathrm{m}^{-3} \cdot \mathrm{d}^{-1}\right), \mathrm{Ch}_{\mathrm{f}}$ and $\mathrm{Ch}_{0}$ are final and initial content of chlorophyll (mg), respectively, and $\mathrm{d}$ is the cultivation time (day).

Microalgal cells were counted using Thoma hemacytometer [22]. Two chambers of the hemacytometer were filled up with culture samples. Cells were counted under a light microscope (Delta Optical Genetic Pro Bino, Warszawa, Poland). The average cell count was multiplied by 10,000 to calculate the number of cells per milliliter of the microalgal culture.

The chlorophyll concentration and cell counting analyzes were performed on the first day of the experiment and then after 5, 10, and 15 days.

\subsection{Statistical Analysis}

All determinations were performed in triplicate. The results were statistically analyzed using the statistical software package for Windows (Statistica version 13.3; Dell Inc., Tulsa, OK, USA). Two-way analysis of variance was used. The significance of differences between the means was assessed using post hoc Duncan test at statistical significance of $p \leq 0.05$. The standard deviation was also determined.

\section{Results and Discussion}

Various methods are used to assess the efficiency of biomass production. The most popular of them are the determination of dry matter [23], measurement of optical density, determination of chlorophyll content using a spectrophotometer, and a method based on counting cells using a counting chamber [24]. In the presented work, differences between the optimal process conditions determined with the use of individual methods were noted. Based on the statistical analysis of the test results, it was found that the photoperiod used, and the $\mathrm{pH}$ of the culture medium had a significant effect on the amount of biomass and the content of chlorophyll a in microalgae cells of the $C$. vulgaris species. However, the factors analyzed in the study did not have a significant effect on the number of microalgae cells.

The amount of biomass in individual photobioreactors at the beginning of the experiment was on average $417 \pm 14.43 \mathrm{mg} \cdot \mathrm{l}^{-1}$. Under LED lighting conditions, the time of the culture entering the stationary growth phase occurred slightly earlier than under SON-T Agro lighting (Figure 2). Depending on other factors, it was generally between the 7th and 9th day of breeding. Similar dependencies in their research were presented by Kim et al. [25]), who assessed the optimal conditions for the production of microalgae Chlorella sp., Dunaliella salina, and Dunaliella sp. biomass and found that the biomass content increased by the 8th measurement day. Similar results were obtained by Hawrot et al. [26] in a study on the production of Chlorella minutissima biomass using aquaculture wastewater. After 10 days, the breeding entered the stationary phase. The inhibition of the growth and development of microalgae between 8 and 10 days may be related to the depletion of nutrients in the culture medium [27].

In optimal culture conditions, higher biomass productivity was obtained on day $4-27.08 \pm 7.80 \mathrm{mg} \cdot \mathrm{L}^{-1} \cdot \mathrm{d}^{-1}$ under SON-T Agro lighting and $25.00 \pm 5.10 \mathrm{mg} \cdot \mathrm{L}^{-1} \cdot \mathrm{d}^{-1}$ under LED lighting (Figure 3). Similar results for $C$. vulgaris biomass productivity $\left(0.04 \pm 0.03 \mathrm{~g} \cdot \mathrm{L}^{-1} \cdot \mathrm{d}^{-1}\right)$ were obtained by Machado et al. [28].

The average amount of biomass in the culture with SON-T Agro illumination ranged from $506 \pm 6.74$ to $546 \pm 7.88 \mathrm{mg} \cdot \mathrm{L}^{-1}$ (Figure 4). The concentration of biomass in the culture depends on the initial inoculum density, but the amount of biomass obtained in the presented studies on the $\mathrm{F} / 2$ substrate was within the range of the results obtained by other authors. Matos et al. [29] in the modified BBM medium obtained $0.59 \mathrm{~g} \cdot \mathrm{L}^{-1}$ of biomass. Similar results were presented by Travieso et al. [30], who cultivated microalgae biomass in diluted nitrogen-rich waste and obtained a maximum of $510 \mathrm{mg} \cdot \mathrm{L}^{-1}$. The highest amount was determined in a photobioreactor illuminated for $18 \mathrm{~h}$ and at $\mathrm{pH}$ 7. Similar results were obtained by Wahidin et al. [31], who investigated the effect of the irradiation cycle on the growth of biomass of Nannochloropsis sp. In addition, the highest values were recorded in 18/6 h cycle. In studies conducted by Amini et al. [32], the highest increase 
in the biomass of microalgae Chlorella vulgaris was recorded in the $16 / 8 \mathrm{~h}$ (light/dark) photoperiod. Different results are presented by Atta et al. [33], who found in their research that the optimal culture conditions for the microalgae $C$. vulgaris occurred in the $12 / 12 \mathrm{~h}$ photoperiod (light/dark), while the lowest biomass increases with continuous lighting of the culture.

A
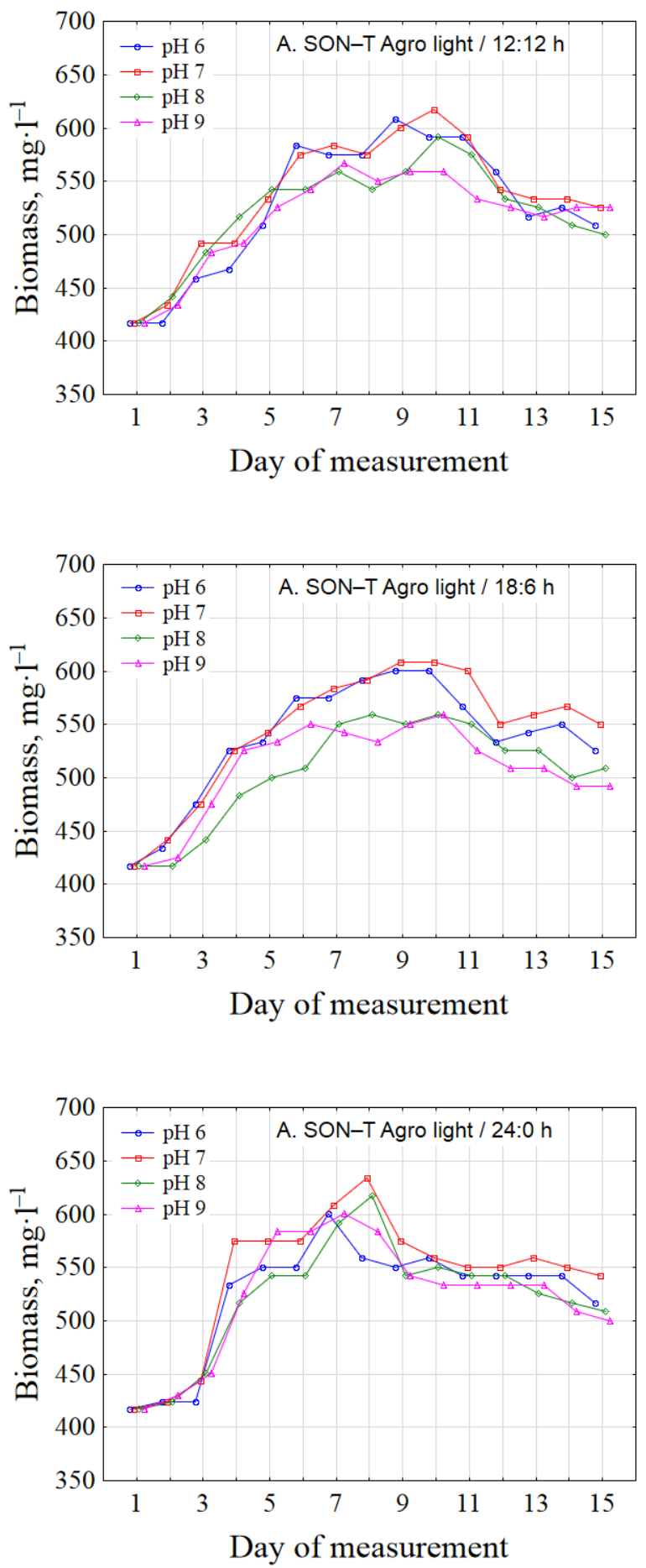

B
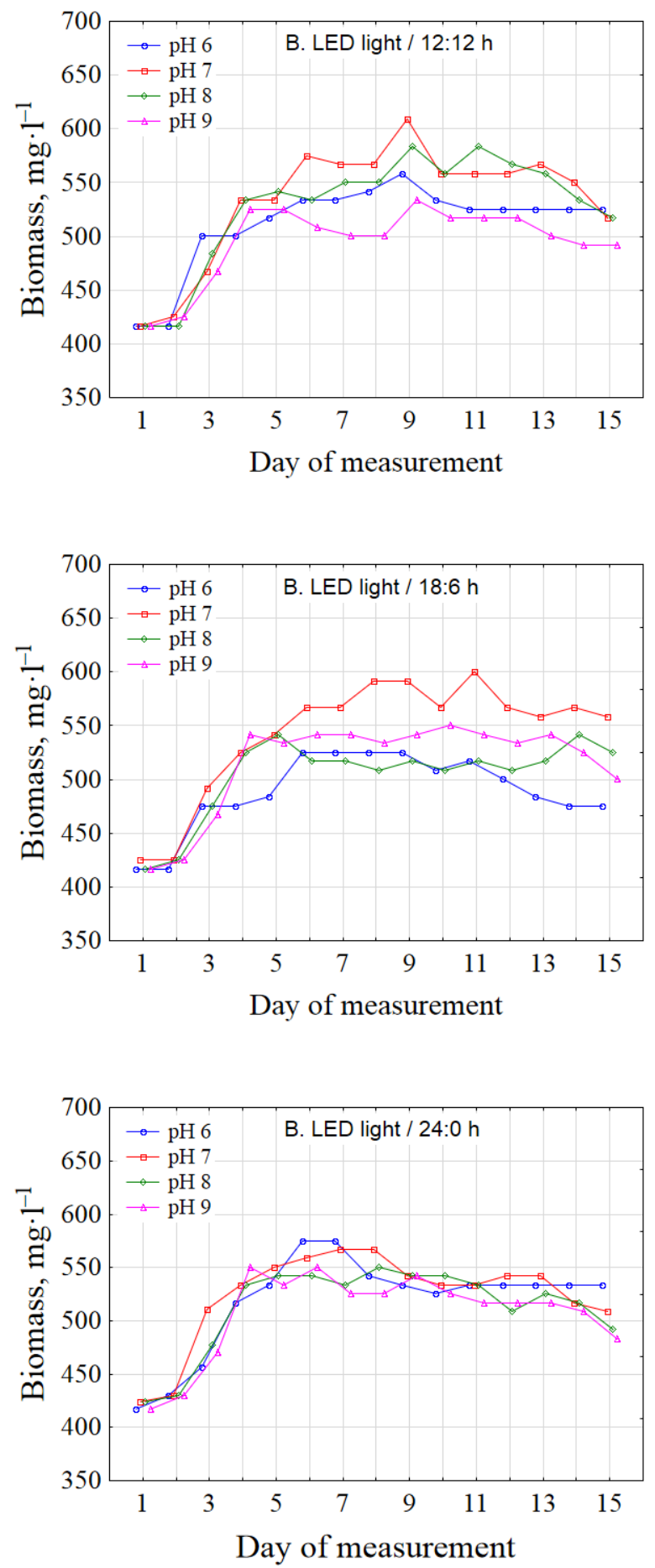

Figure 2. Dynamics of the growth of microalgae biomass in SON-T Agro light (A) and light-emitting diode (LED) light (B) during different light:dark cycle. 

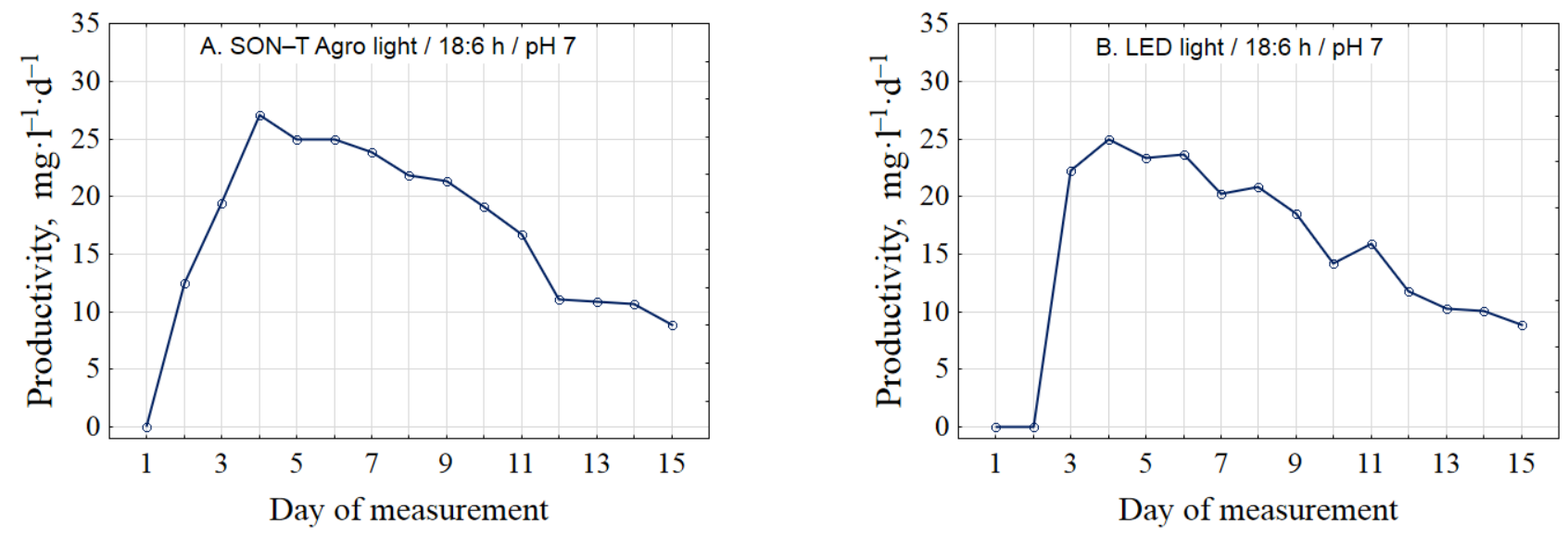

Figure 3. Biomass productivity under optimal culture conditions in SON-T Agro light (A) and LED light (B).

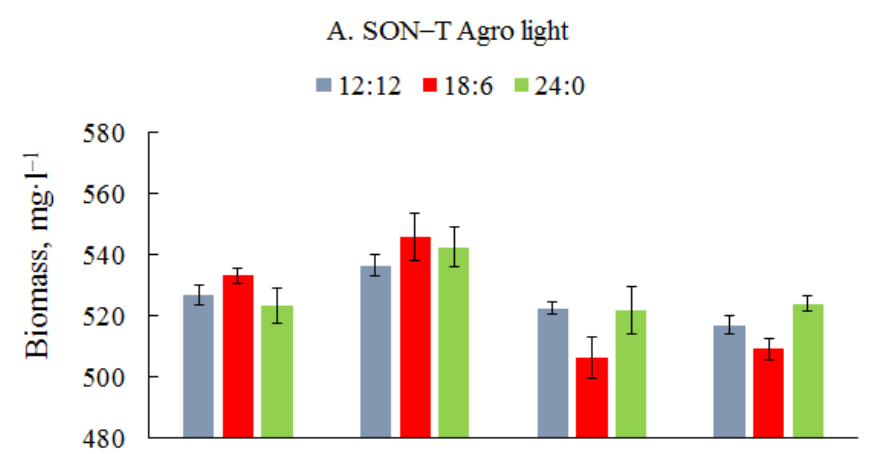

$\mathrm{pH}$

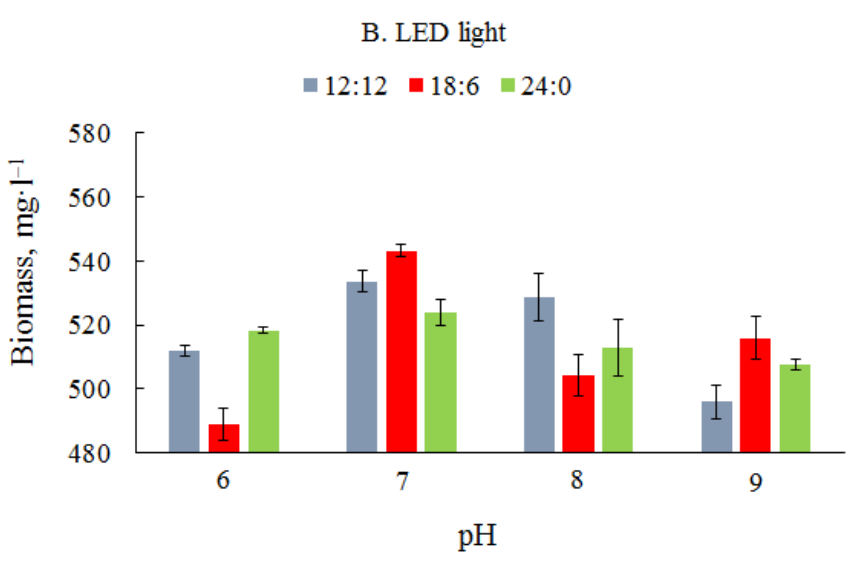

$\mathrm{pH}$

Figure 4. The average amount of microalgae biomass in SON-T Agro light (A) and LED light (B) during different light:dark cycle.

Under LED light conditions, the average amount of biomass ranged from $489 \pm 5.00$ to $543 \pm 1.92 \mathrm{mg} \cdot \mathrm{L}^{-1}$. As in the case of sodium lighting, the highest values were recorded in the $18 / 6 \mathrm{~h}$ cycle and $\mathrm{pH} 7$. The amount of biomass obtained in a culture medium with a neutral $\mathrm{pH}$, regardless of the type of lighting and the time of lighting culture, was generally significantly different from the other values. Khalil et al. [34] investigated the effect of $\mathrm{pH}$ on the growth of Dunaliella bardawil and Chlorella ellipsoidea and found that although these microalgae could grow over a wide $\mathrm{pH}$ range from 4 to $9 / 10$, the greatest dry matter gain for $D$. bardawil was at $\mathrm{pH} 7.5$, and for C. ellipsoidea, at alkaline $\mathrm{pH}$ (9-10). In a study by Qiu et al. [35], the highest increase in Chlorella sorokiniana biomass was obtained at $\mathrm{pH}$ 6. These results indicate the need to conduct research on the optimization of biomass production conditions, which change significantly depending on the type of microalgae.

According to Gong et al. [36], it is very important to keep the $\mathrm{pH}$ constant during cultivation. Methods with control of optimal $\mathrm{pH}$ value increased the growth of microalgae by over $56 \%$.

Chlorophyll content at the beginning of the experiment in all objects was $46 \pm 6.17 \mathrm{mg} \cdot \mathrm{m}^{-3}$ (Figure 5). In the photobioreactors illuminated by SON-T Agro light, the highest values were determined on the fifth day of the experiment and a significant decrease in the content of chlorophyll and in microalgae cells in subsequent dates. Similar relationships were presented by Lakaniemi et al. [37] who, while examining the growth of C. vulgaris in tubular photobioreactors, found that in the initial phase of growth, the content of chlorophyll a increased, and then, after the 5th day of the experiment, the amount of assimilation pigment decreased almost to zero. Such a significant decrease in chlorophyll 
content, according to these authors, was related to the reduction of nutrients in the culture medium. In the presented research, a similar situation was observed in the conditions of cultivating with LED light. A significant increase in the content of chlorophyll was observed already with the second measuring time. The highest content of assimilated pigment was determined in the photobioreactor at $18 / 6 \mathrm{~h}$ cycle and $\mathrm{pH} 7$. Similar results were obtained by Eriksen et al. [38] while breeding Chlamydomonas reinhardtii and Chlorella sp. in a gas-tight photobioreactor, and Perner-Nochta et al. [39] conducted a photoautotrophic culture of C. vulgaris. According to Lakaniemi et al. [37], determining the content of chlorophyll a is not a useful measure of biomass concentration due to the lack of correlation between the content of chlorophyll and the optical density of the culture. The content of chlorophyll a may also be misleading due to the differences in the size of the analyzed cells [40].

A
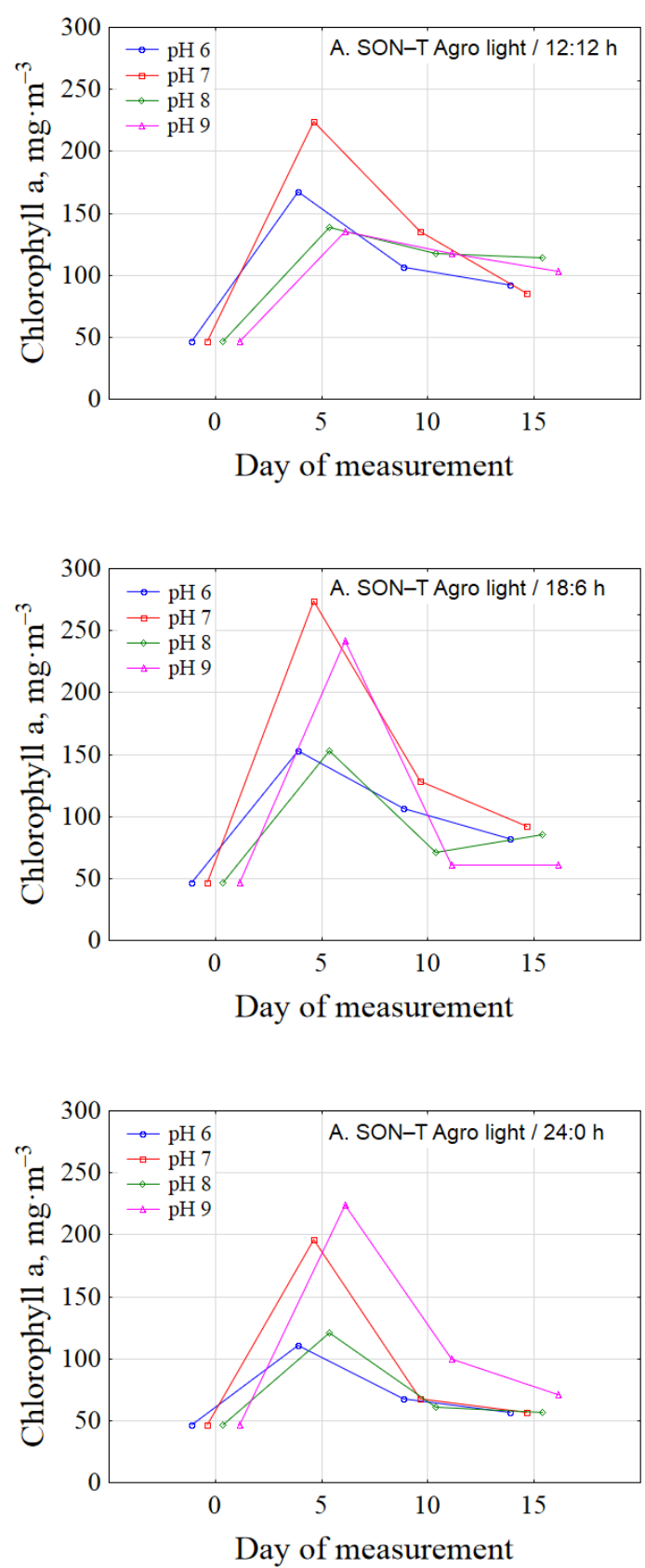

B
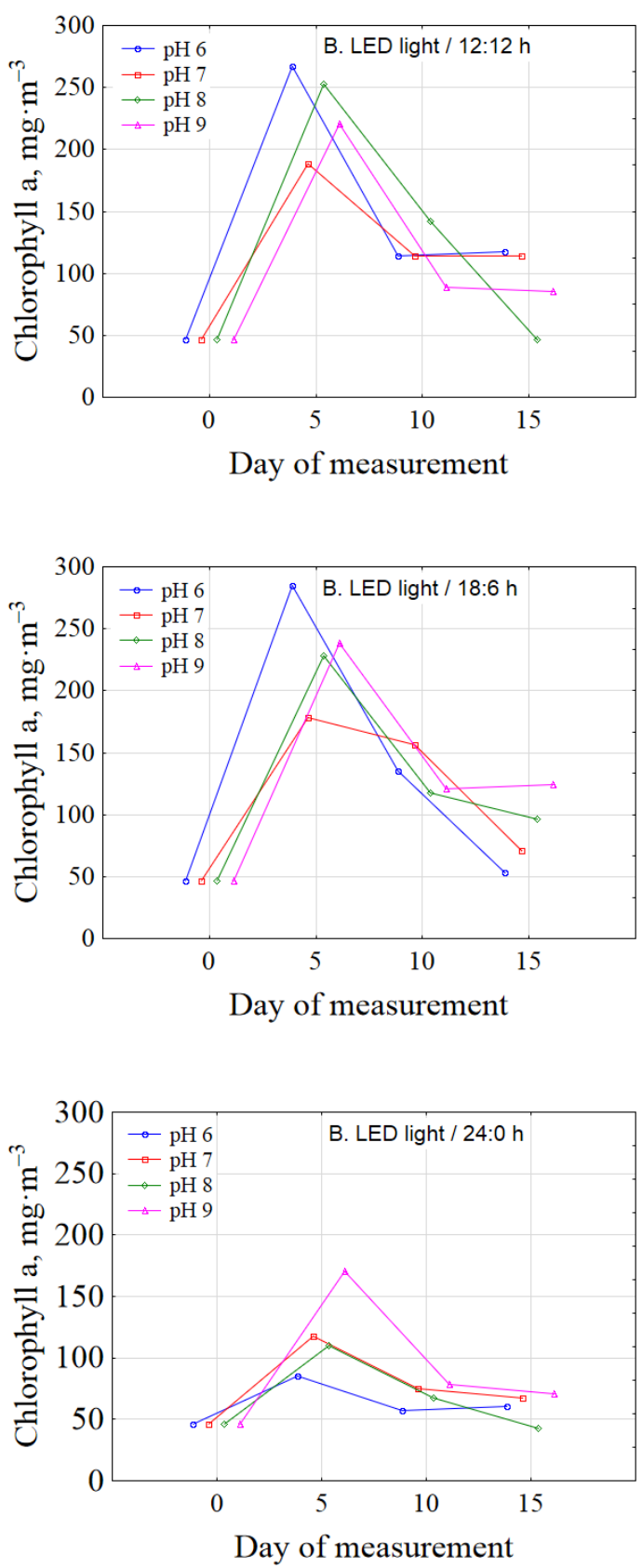

Figure 5. Dynamics of chlorophyll a content in microalgal in SON-T Agro light (A) and LED light (B) during different light:dark cycle. 
The highest chlorophyll productivity was on day 5 (Figure 6). Content of microalgal chlorophyll in optimal condition was $24.21 \pm 8.89$ and $26.34 \pm 2.01 \mathrm{mg} \cdot \mathrm{m}^{-3} \cdot \mathrm{d}^{-1}$, under HPS and LED lightening, respectively.
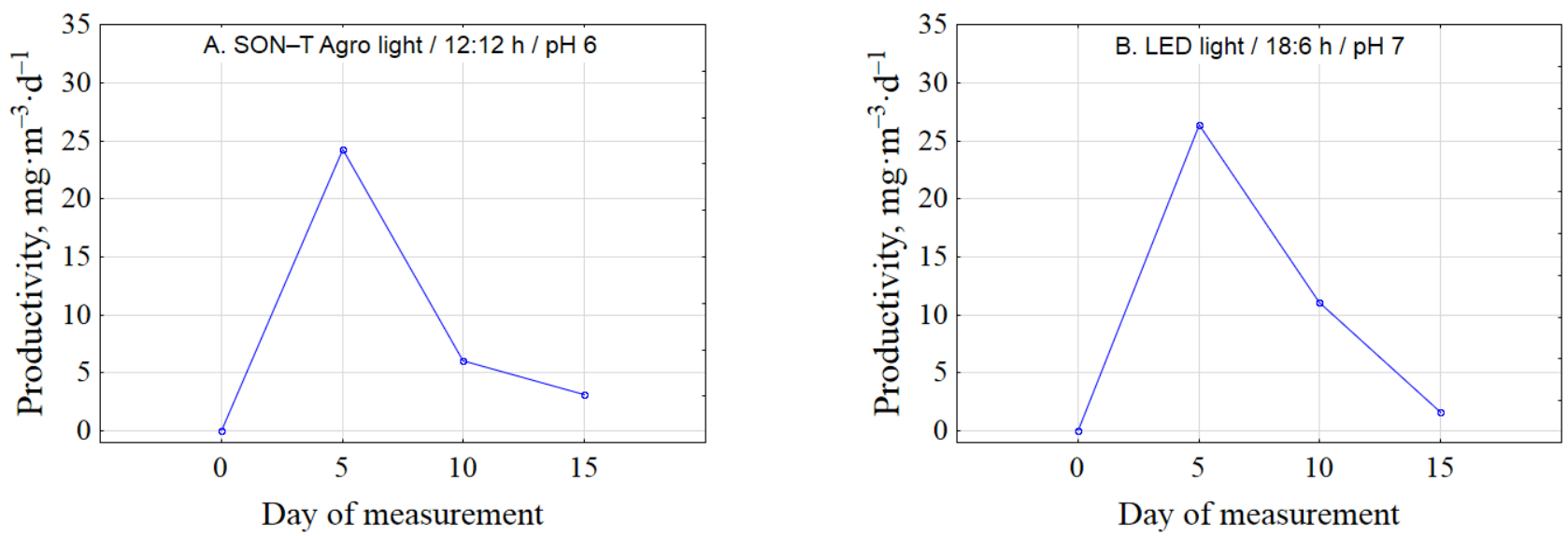

Figure 6. Chlorophyll productivity of C. vulgaris in SON-T Agro light (A) and LED light (B).

The mean content of chlorophyll a with SON-T Agro illumination ranged from $70+10.11$ to $135 \pm 6.17 \mathrm{mg} \cdot \mathrm{L}^{-1}$ (Figure 7). The highest content of assimilated pigment for this type of light was determined in a photobioreactor illuminated for $18 \mathrm{~h}$ and at $\mathrm{pH}$ 7. In the study by Khalil et al. [33], two strains of Dunaliella bardawil and Chlorella ellipsoidea at different $\mathrm{pH}$ variants showed that the neutral $\mathrm{pH}$ of the culture medium favored the accumulation of chlorophyll a and other assimilation pigments. The $\mathrm{pH}$ of the culture medium affects the entire process of microalgae cultivation. Unfavorable $\mathrm{pH}$ values influence the efficiency of nutrient absorption and metabolite production [41]. Additionally, $\mathrm{pH}$ conditions can cause calcium precipitation in some microalgae cultures [42]. Del Campo [43] found that the optimal $\mathrm{pH}$ for photosynthesis is generally lower than the requirements for growth and showed that $\mathrm{pH}$ values ranging from 6 to 9 stimulate carotogenesis for Muriellopsis sp. Under LED lighting, the mean amount of chlorophyll ranged from $62 \pm 6.72$ to $136 \pm 14.13 \mathrm{mg} \cdot \mathrm{L}^{-1}$. Contrary to sodium lighting, the highest values were obtained at the photoperiod 12/12 and $\mathrm{pH} 6$. No significant differences were found between the content of chlorophyll in microalgae cells at the highest values of chlorophyll a. The study of Yan et al. [44] on the effect of different wavelengths of LED light on the cultivation of C. vulgaris confirmed the effectiveness of this type of lighting in the production of biomass from algae; the use of red light has a positive effect on the content of chlorophyll a. Mohsenpour et al. [45] confirmed the dependence of red light on the increase in chlorophyll content and in C. vulgaris cells and the decrease in biomass content.

The initial number of microalgae cells in the culture was $9.3 \times 10^{5}$ (Figure 8). A significant increase in the number was recorded between the first and second measurement dates for SON-T Agro and LED light-illuminated photobioreactors. After this measurement date, the culture entered the stationary growth phase. With LED illumination at the end of the experiment in the two photoperiods, the culture had already reached the death phase. Many authors have shown a similar relationship. La et al. [46], examining the effect of glucose on the growth of $C$. vulgaris, showed that on the fifth day of the experiment, cell growth entered the stationary phase $\left(20 \times 10^{6}\right.$ of microalgal cells). The studies of Pagnanelli et al. [47] on the effect of the addition of nitrate and glucose to the culture medium on the growth of $C$. vulgaris and Nannochloropsis oculata cells showed, as in the presented work, a large increase in the initial phase of the experiment. The number of C. vulgaris cells ranged from $9.4 \times 10^{9}$ to $12 \times 10^{9}$. This was due to the addition of nutrients to the medium, which stimulates the growth and development of microalgae [48]. On the other hand, studies by Glacio et al. [49], concerning the effect of nutrients on the growth of 
C. vulgaris biomass, showed the growth of algae cells only up to the 8th day of measurement, after which the culture entered the death phase.
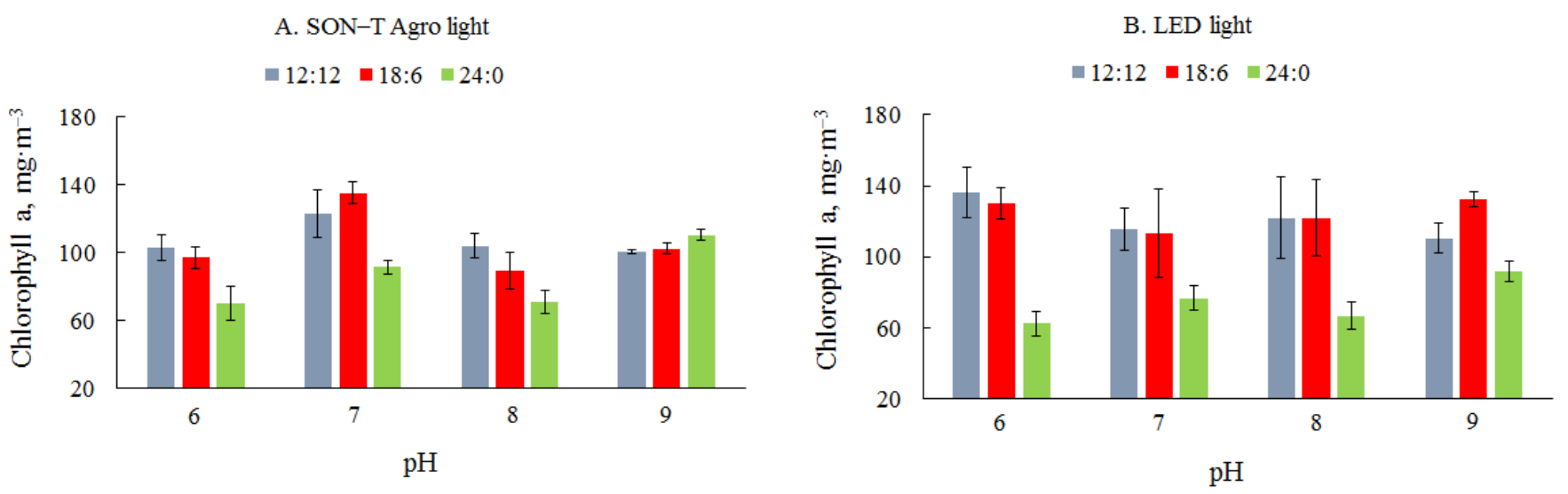

Figure 7. The average amount of chlorophyll a in microalgal biomass in (A) SON-T Agro light and (B) LED light during different light:dark cycle.

The mean values of the number of microalgae cells indicate that the time of lighting culture, and the $\mathrm{pH}$ had no significant effect on the obtained values (Figure 9). Under SON-T Agro lighting, the highest values were recorded at the $18 / 6 \mathrm{~h}$ photoperiod $\left(19.3 \times 10^{5}-20.8 \times 10^{5}\right)$, and under LED lighting, the highest average number of microalgae cells was recorded at $12 / 12 \mathrm{~h}\left(18.9 \times 10^{5}-20.8 \times 10^{5}\right)$, however, as shown in Figure 5, they did not differ significantly from other lighting conditions. There was also no significant influence of medium $\mathrm{pH}$ on the analyzed parameters. On the other hand, the research by Vaičiulyte et al. [50] were carried out under constant lighting conditions and results showed significant differences in the number of $C$. vulgaris cells depending on cultivation conditions (batch growth or semi-continuous culture) and types of culture media. The analysis of the number of cells used to quantify the biomass does not define the stage of development of the culture and the size of the cells [51].

A positive correlation was found between the results of different methods of biomass determination in culture, however, a high R-factor was obtained mainly between the gravimetric measurement and the determination of the number of microalgae cells in the Thoma chamber, regardless of the type of lighting $(r=0.76$ for sodium light and $r=0.83$ for LED light). Based on the results of own research and the results of other authors [52], it can be concluded that the chlorophyll measurement method is not the best indicator of the estimation of biomass. Chlorophyll is a nitrogen-rich compound [53]. During cultivation, under $\mathrm{N}$ depletion in culture medium, chlorophyll is degraded to utilize nitrogen [54]. The chlorophyll content will decrease, while the amount of biomass may increase. The direct methods are more reliable. According to Rath et al. [20], such a method is a gravimetric measurement performed with a moisture analyzer, similarly to the presented work. This method is not only accurate but also much faster compared to the analyzes performed by traditional biomass drying in the oven. 
A

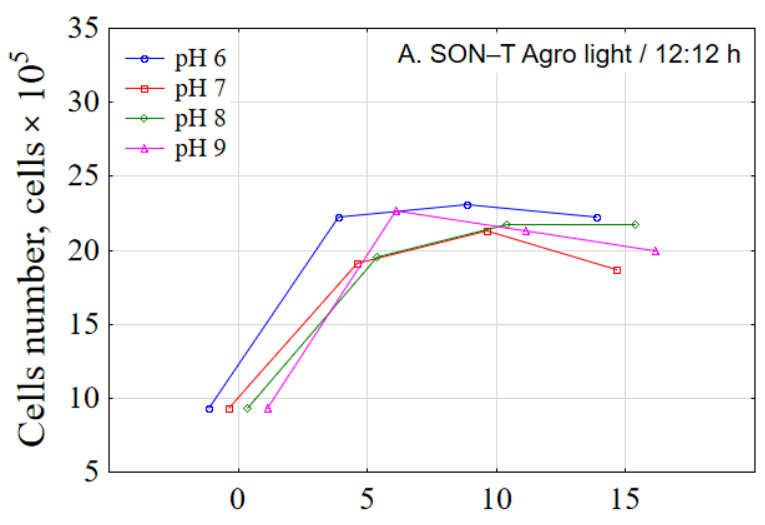

Day of measurement

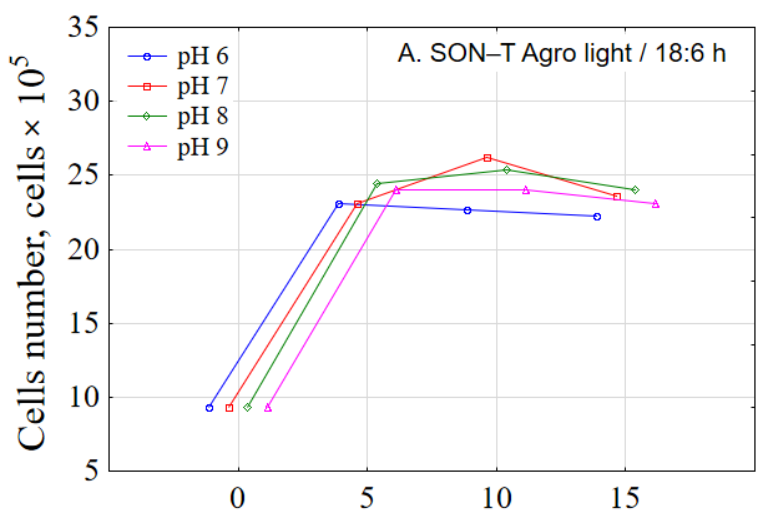

Day of measurement

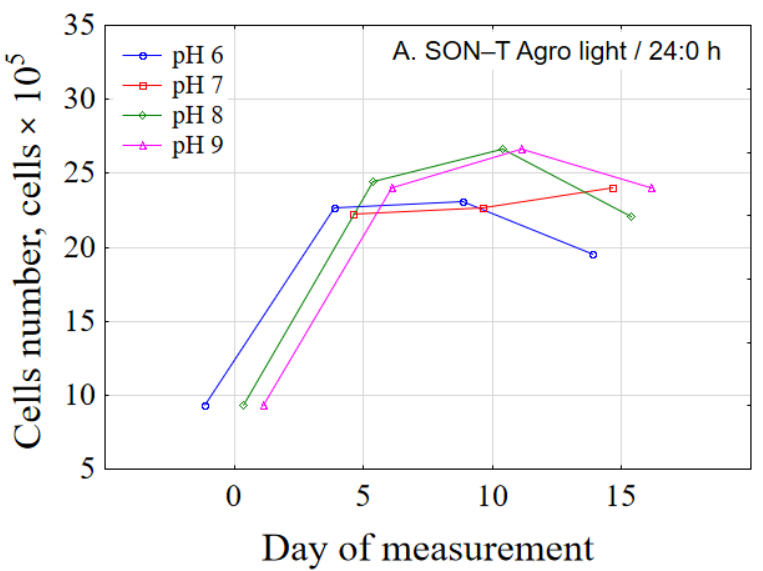

B

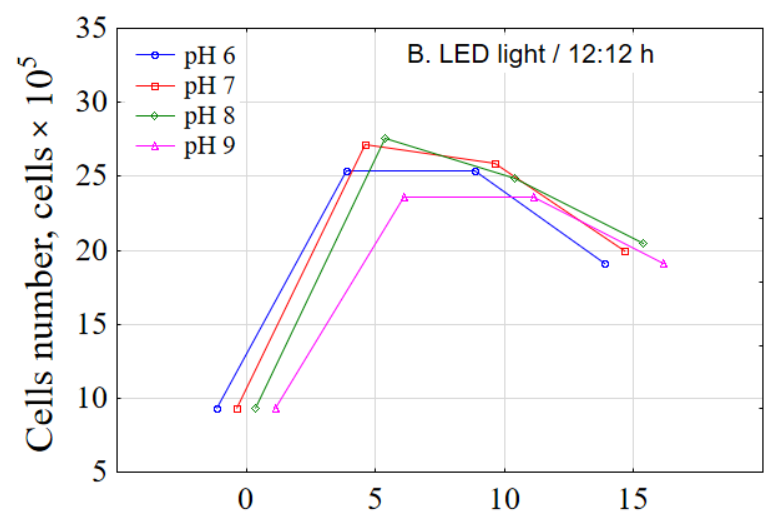

Day of measurement

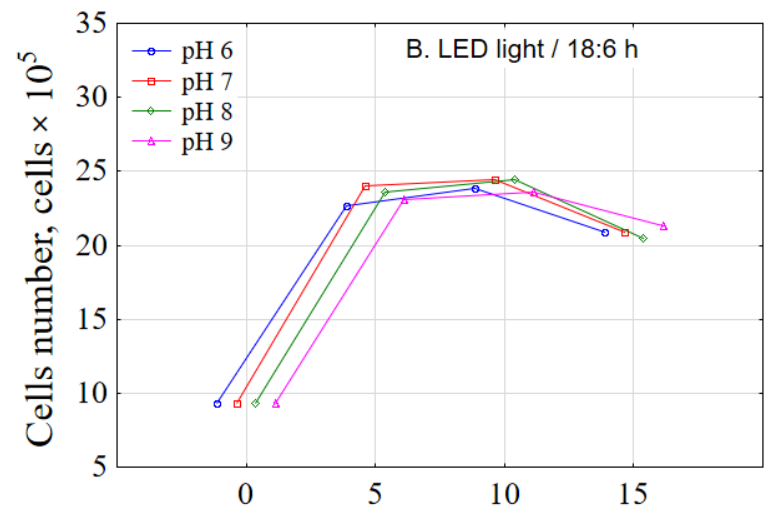

Day of measurement

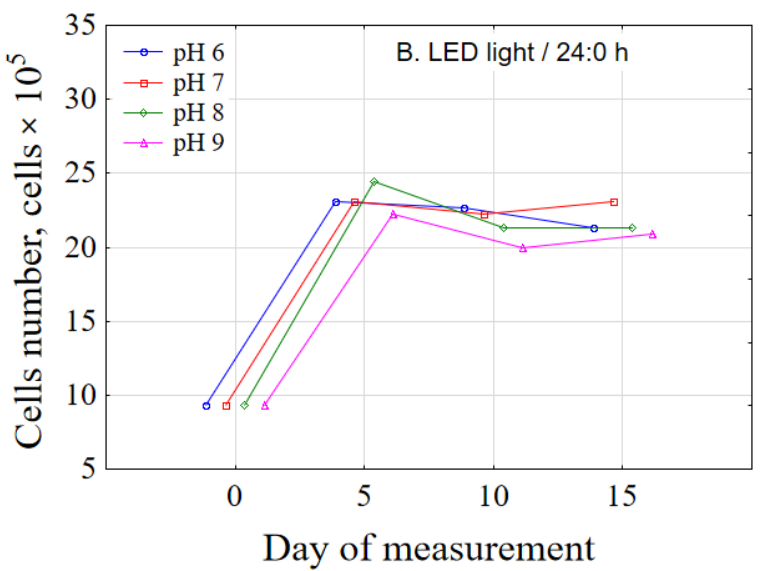

Figure 8. Dynamics of algae cell changes in culture in SON-T Agro light (A) and LED light (B) during different light:dark cycle. 

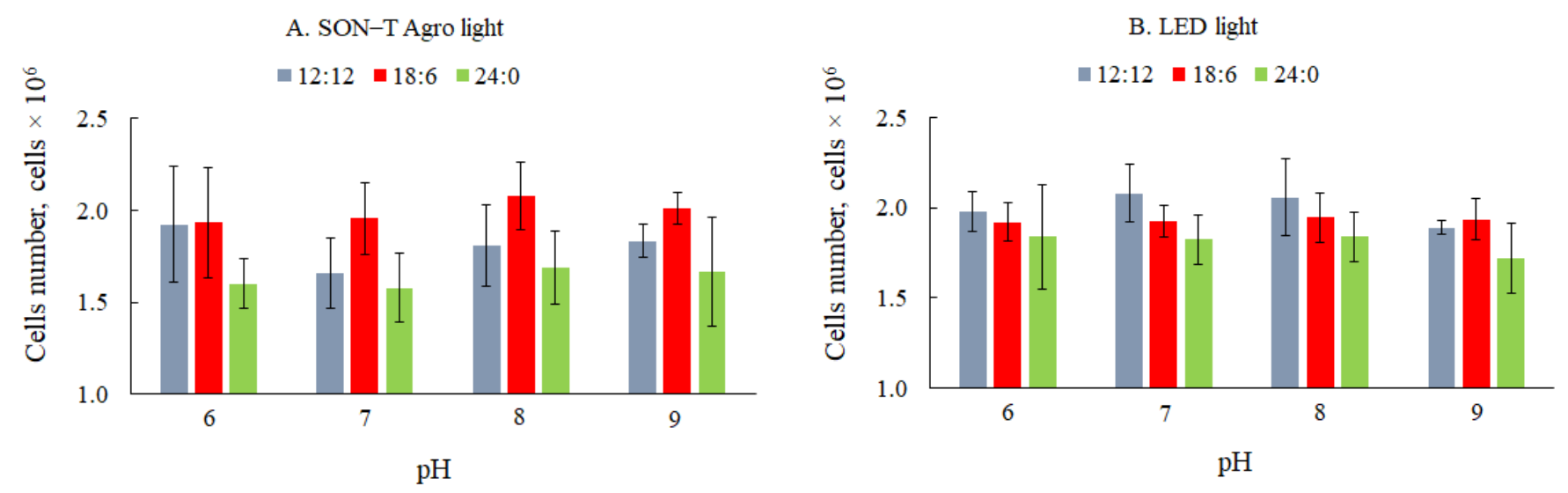

Figure 9. The average number of algae cells in culture in SON-T Agro light (A) and LED light (B) during different light:dark cycle.

\section{Conclusions}

The production of microalgae biomass requires the selection of optimal cultivation conditions. The most important parameters are the type and the time of lighting, which will also be important for the economy of the process. All factors used in the research had a significant impact on the amount of biomass. Depending on the method used (direct, indirect), different results were obtained. For dry mass measurement, the optimal culture conditions were recorded using 18/6 h light/dark cycle and $\mathrm{pH}$ of $7-546 \pm 7.88 \mathrm{mg} \cdot \mathrm{L}^{-1}$ for high-pressure sodium light and $543 \pm 1.92 \mathrm{mg} \cdot \mathrm{L}^{-1}$ for light-emitting diode. The maximum content of chlorophyll a was determined in the 12/12 h light/dark cycle, $\mathrm{pH} 6$, under light-emitting diode $\left(136 \pm 14.13 \mathrm{mg} \mathrm{m}^{-3}\right)$ and $18 / 6 \mathrm{~h}, \mathrm{pH} \mathrm{7,} \mathrm{under} \mathrm{sodium} \mathrm{light}$ $\left(135 \pm 6.17 \mathrm{mg} \mathrm{m}^{-3}\right)$. The biomass and chlorophyll productivity in optimal conditions under HPS and LED light was $27.08 \pm 7.80$ and $24.21 \pm 8.89 \mathrm{mg} \cdot \mathrm{m}^{-3} \cdot \mathrm{d}^{-1}$ and $25.00 \pm 5.1$ and $26.34 \pm 2.01 \mathrm{mg} \cdot \mathrm{m}^{-3} \cdot \mathrm{d}^{-1}$, respectively. The highest number of microalgae cells $\left(2.1 \times 10^{6}\right)$ was obtained at $\mathrm{pH} 7$ and photoperiod $18 / 6 \mathrm{~h}$ under sodium light, and $12 / 12 \mathrm{~h}$ under light-emitting diode. The results for all measurements suggest that particular methods can be used alternately during the determination of biomass content. However, if other indicators (cell number and chlorophyll a content) are used for biomass validation, the optimal culture parameters may change with different types of light. Considering the results, the most accurate method for biomass evaluation is gravimetric dry weight assessment $>$ cell counting $>$ chlorophyll content.

Author Contributions: Conceptualization, P.R. and M.H.-P.; methodology, M.H.-P.; validation, P.R. and M.H.-P.; formal analysis, P.R. and M.H.-P.; investigation, P.R.; writing - original draft preparation, P.R. and M.H.-P.; writing-review and editing, P.R. and M.H.-P.; visualization, P.R and M.H.-P.; supervision, M.H.-P. All authors have read and agreed to the published version of the manuscript.

Funding: This research received no external funding.

Institutional Review Board Statement: Not applicable.

Informed Consent Statement: Not applicable.

Data Availability Statement: The data presented in this study are available on request from the corresponding author.

Conflicts of Interest: The authors declare no conflict of interest.

\section{Abbreviations}

LED light light-emitting diode

HPS light high-pressure sodium light 


\section{References}

1. Guiry, M.D. How many species of algae are there? J. Phycol. 2012, 48, 1057-1063. [CrossRef]

2. Singh, R.N.; Sharma, S. Development of suitable photobioreactor for algae production-A review. Renew. Sustain. Energy Rev. 2012, 16, 2347-2353. [CrossRef]

3. Patyna, A.; Biłos, Ł.; Płaczek, M.; Witczak, S. Productivity of microalgae Chlorella vulgaris in laboratory condition. Inżynieria Ekol. 2017, 18, 99-105. [CrossRef]

4. Mata, T.M.; Martins, A.A.; Caetano, N.S. Microalgae for biodiesel production and other applications: A review. Renew. Sustain. Energy Rev. 2010, 14, 217-232. [CrossRef]

5. Miao, X.; Wu, Q. Biodiesel production from heterotrophic microalgal oil. Bioresour. Technol. 2006, 97, 841-846. [CrossRef]

6. Lorenz, R.T.; Cysewski, G.R. Commercial potential for Haematococcus microalga as a natural source of astaxantin. Trends Biotechnol. 2003, 18, 160-167. [CrossRef]

7. Spolaore, P.; Joannis-Cassan, C.; Duran, E.; Isambert, A. Commercial applications of microalgae. J. Biosci. Bioeng. 2006, 101, 87-96. [CrossRef]

8. Chisti, Y. Biodiesel from microalgae. Biotechnol. Adv. 2007, 25, 294-306. [CrossRef] [PubMed]

9. Chen, C.Y.; Yeh, K.L.; Aisyah, R.; Lee, D.J.; Chang, J.S. Cultivation, photobioreactor design and harvesting of microalgae for biodiesel production: A critical review. Bioresour. Technol. 2011, 102, 17-81. [CrossRef] [PubMed]

10. Mohsenpour, S.F.; Willoughby, N. Luminescent photobioreactor design for improved algal growth and photosynthetic pigment production through spectral conversion of light. Bioresour. Technol. 2013, 142, 147-153. [CrossRef] [PubMed]

11. Chen, C.Y.; Zhao, X.Q.; Yen, H.W.; Ho, S.H.; Cheng, C.L.; Lee, D.J.; Bai, F.W.; Chang, J.S. Microalgae-based carbohydrates for biofuel production. Biochem. Eng. J. 2013, 78, 1-10. [CrossRef]

12. Rai, M.P.; Gautom, T.; Sharma, N. Effect of salinity, $\mathrm{pH}$, light intensity on growth and lipid production of microalgae for bioenergy application. Int. J. Biol. Sci. 2015, 15, 260-267. [CrossRef]

13. Meseck, S.L.; Alix, J.H.; Wikfors, G.H. Photoperiod and light intensity effects on growth and utilization of nutrients by the aquaculture feed microalga, Tetraselmis chui (PLY429). Aquaculture 2005, 246, 393-404. [CrossRef]

14. Carvalho, A.P.; Silva, S.O.; Baptista, J.M.; Malcata, F.X. Light requirements in micro-algal photobioreactors: An overview of biophotonic aspects. Appl. Microbiol. Biotechnol. 2011, 89, 1275-1288. [CrossRef] [PubMed]

15. Korbee, N.; Figueroa, F.; Aguilera, J. Effect of light quality on the accumulation of photosynthetic pigments, proteins and mycosporine-like amino acids in the red alga Porphyra leucosticte (Bangiales, Rhodophyta). J. Photochem. Photobiol. 2005, 80, 71-78. [CrossRef]

16. Loera-Quezada, M.M.; Angeles, G.; Olguín, E.J. Effect of irradiance on the cell density, size and lipid accumulation of Neochloris oleoabundans. Rev. Latinoam. Biotechnol. Ambient. Algal 2011, 2, 81-92.

17. Juneja, A.; Ceballos, R.M.; Murthy, G.S. Effects of Environmental Factors and Nutrient Availability on the Biochemical Composition of Algae for Biofuels Production: A Review. Energies 2013, 6, 4607-4638. [CrossRef]

18. Rai, S.V.; Rajashekhar, M. Effect of $\mathrm{pH}$, salinity and temperature on the growth of six species of marine phytoplankton. J. Algal Biomass Util. 2014, 5, 55-59.

19. Guillard, R.R.L.; Ryther, J.J. Studies of marine planktonic diatoms in Cyclotella nana Hustedt and Detonula confervacea Cleve. Can. J. Microbiol. 1962, 8, 229-239. [CrossRef]

20. Ratha, S.K.; Rao, P.H.; Govindaswamy, K.; Jaswin, R.S.; Lakshmidevi, R.; Bhaskar, S.; Chinnasamy, S. A rapid and reliable method for estimating microalgal biomass using a moisture analyser. J. Appl. Phycol. 2016, 28, 1725-1734. [CrossRef]

21. Polish Standards PN-86 C-05560/02. Water and Waste Water. Tests for Chlorophyll in Surface Water, Determination of Chlorophyll a in Planktonic Algae by Spectrophotometric Monochromatic Method with Correction for Pheopigments Alpha; 1986. Polish Committee for Standardisation. Available online: https:/ / sklep.pkn.pl/pn-c-05560-02-1986p.html (accessed on 9 November 2020). (In Polish).

22. Dökümcüoğlu, V.E.; Yılmaz, M. Assessment of Cell Counting Method Based on Image Processing for a Microalga Culture. Mediterr. Fish. Aquac. Res. 2020, 3, 75-81.

23. Yoo, C.; Jun, S.Y.; Lee, J.Y.; Ahn, C.Y.; Oh, H.M. Selection of microalgae for lipid production under high levels carbon dioxide. Bioresour. Technol. 2010, 101, 71-74. [CrossRef]

24. Salim, S.; Bosma, R.; Vermuë, M.H.; Wijffels, R.H. Harvesting of microalgae by bio-flocculation. J. Appl. Phys. 2011, 23, 849-855. [CrossRef] [PubMed]

25. Kim, W.; Park, J.M.; Gim, G.H.; Jeong, S.H.; Kang, S.H.; Kang, C.M.; Kim, D.J.; Kim, S.W. Optimization of culture conditions and comparison of biomass productivity of three green algae. Bioprocess Biosyst. Eng. 2012, 35, 19-27. [CrossRef]

26. Hawrot-Paw, M.; Koniuszy, A.; Gałczyńska, M.; Zając, G.; Szyszlak-Bargłowicz, J. Production of Microalgal Biomass Using Aquaculture Wastewater as Growth Medium. Water 2019, 12, 106. [CrossRef]

27. Sacristán de Alva, M.; Luna-Pabello, V.M.; Cadena, E.; Ortiz, E. Green microalgae Scenedesmus acutus grown on municipal wastewater to couple nutrient removal with lipid accumulation for biodiesel production. Bioresour. Technol. 2013, 146, 744-748. [CrossRef] [PubMed]

28. Machado, A.; Pereira, H.; Costa, M.; Carvalho, B.; Soares, M.; Quelhas, P.; Silva, J.T.; Trovão, M.; Barros, A.; Varela, J.; et al. Development of an Organic Culture Medium for Autotrophic Production of Chlorella vulgaris Biomass. Appl. Sci. 2020, 10, 2156. [CrossRef] 
29. Matos, Â.P.; Ferreira, W.B.; de Oliveira Torres, R.C.; Ito Morioka, L.R.; Machado Canella, M.H.; Rotta, J.; da Silva, T.; Siegel Moecke, E.H.; Sant'Anna, E.S. Optimization of biomass production of Chlorella vulgaris grown in desalination concentrate. J. Appl. Phycol. 2015, 27, 1473-1483. [CrossRef]

30. Travieso, L.; Benítez, F.; Sánchez, E.; Borja, R.; Martín, A.; Colmenarejo, M.F. Batch mixed culture of Chlorella vulgaris using settled and diluted piggery waste. Ecol. Eng. 2006, 28, 158-165. [CrossRef]

31. Wahidin, S.; Idris, A.; Shaleh, S.R. The influence of light intensity and photoperiod on the growth and lipid content of microalgae Nannochloropsis sp. Bioresour. Technol. 2013, 129, 7-11. [CrossRef] [PubMed]

32. Amini, K.Z.; Seyfadabi, J.; Ramezanpur, Z. Effect of light intensity and photoperiod on biomass and fatty acid composition of the microalgae, Chlorella vulgaris. Aquac. Int. 2012, 20, 41-49. [CrossRef]

33. Atta, M.; Idris, A.; Bukhari, A.; Wahidin, S. Intensity of blue LED light: A potential stimulus for biomass and lipid content in fresh water microalgae Chlorella vulgaris. Bioresour. Technol. 2013, 148, 373-378. [CrossRef] [PubMed]

34. Khalil, Z.I.; Asker, M.M.; El-Sayed, S.; Kobbia, I.A. Effect of $\mathrm{pH}$ on growth and biochemical responses of Dunaliella bardawil and Chlorella ellipsoidea. World J. Microbiol. Biotechnol. 2010, 26, 1225-1231. [CrossRef]

35. Qiu, R.; Gao, S.; Lopez, P.A.; Ogden, K.L. Effects of pH on cell growth, lipid production and CO2 addition of microalgae Chlorella sorokiniana. Algal Res. 2017, 28, 192-199. [CrossRef]

36. Gong, Q.; Feng, Y.; Kang, L.; Luo, M.; Yang, J. Effects of light and pH on cell density of Chlorella vulgaris. Energy Procedia 2014, 61, 2012-2015. [CrossRef]

37. Lakaniemi, A.M.; Intihar, V.M.; Tuovinen, O.H.; Puhakka, J.A. Growth of Chlorella vulgaris and associated bacteria in photobioreactors. Microb. Biotechnol. 2011, 5, 69-78. [CrossRef] [PubMed]

38. Eriksen, N.T.; Riisgård, F.K.; Gunther, W.S.; Iversen, J.J.L. On-line estimation of $\mathrm{O}_{2}$ production, $\mathrm{CO}_{2}$ uptake, and growth kinetics of microalgal cultures in a gas-tight photobioreactor. J. Appl. Phycol. 2007, 19, 161-174. [CrossRef]

39. Perner-Nochta, I.; Lucumi, A.; Posten, C. Photoautotrophic cell tissue culture in a tubular photobioreactor. Eng. Life Sci. 2007, 7, 127-135. [CrossRef]

40. Griffiths, M.J.; Garcin, C.; van Hille, R.P.; Harrison, S.T. Interference by pigment in the estimation of microalgal biomass concentration by optical density. J. Microbiol. Methods 2011, 85, 119-123. [CrossRef]

41. Morais, M.G.; Vas, B.S.; Morais, E.G.; Costa, J.A.V. Biologically active metabolites synthesized by microalgae. Biomed. Res. Int. 2015, 2015, 835761. [CrossRef] [PubMed]

42. Sirisansaneeyakul, S.; Singhasuwan, S.; Choorit, W.; Phoopat, N.; Garcia, J.L. Photoautotrophic production of lipids by some Chlorella strains. Mar. Biotechnol. 2011, 13, 928-941. [CrossRef]

43. Del Campo, J.A.; Moreno, J.; Rodríguez, H.; Vargas, M.A.; Rivas, J.; Guerrero, M.G. Carotenoid content of chlorophycean microalgae: Factors determining lutein accumulation in Muriellopsis sp. (Chlorophyta). J. Biotechnol. 2000, 76, 51-59. [CrossRef]

44. Yan, C.; Zhao, Y.; Zheng, Z.; Xingzhang, L. Effects of various LED light wavelengths and light intensity supply strategies on synthetic high-strength wastewater purification by Chlorella vulgaris. Biodegradation 2013, 24, 721-732. [CrossRef] [PubMed]

45. Mohsenpour, S.F.; Richards, B.; Willoughby, N. Spectral conversion of light for enhanced microalgae growth rates and photosynthetic pigment production. Bioresour. Technol. 2012, 125, 75-81. [CrossRef]

46. La, A.; Perré, P.; Taidi, B. Process for symbiotic culture of Saccharomyces cerevisiae and Chlorella vulgaris for in situ $\mathrm{CO}_{2} \mathrm{mitigation}$. Appl. Microbiol. Biotechnol. 2019, 103, 731-745. [CrossRef] [PubMed]

47. Pagnanelli, F.; Altimari, P.; Trabucco, F.; Toro, L. Mixotrophic growth of Chlorella vulgaris and Nannochloropsis oculata: Interaction between glucose and nitrate. J. Chem. Technol. Biotechnol. 2014, 89, 652-661. [CrossRef]

48. Daliry, S.; Hallajisani, A.; Roshandeh, J.M.; Nouri, H.; Golzary, A. Investigation of optimal condition for Chlorella vulgaris microalgae growth. GJESM 2017, 3, 217-230. [CrossRef]

49. Glácio, A.; Dilliani, L.; Clarice, S.; José Narciso, S.; André, A. Influence of nutrients on biomass and oil yield from microalgae Chlorella vulgaris for biodiesel production. Rev. Ciência Agronômica 2020, 51, e20165285. [CrossRef]

50. Vaičiulytė, S.; Padovani, G.; Kostkevičienė, J.; Carlozzi, P. Batch Growth of Chlorella Vulgaris CCALA 896 versus Semi-Continuous Regimen for Enhancing Oil-Rich Biomass Productivity. Energies 2014, 7, 3840-3857. [CrossRef]

51. Guillard, R.R.; Sieracki, M.S. Counting cells in cultures with the light microscope. In Algal Culturing Techniques; Andersen, R.A., Ed.; Elsevier Academic Press: Amsterdam, The Netherlands, 2005; pp. 239-252.

52. Ramaraj, R.; Tsai, D.D.W.; Chen, P.H. Chlorophyll is not accurate measurement for algal biomass. Chiang Mai J. Sci. 2013, 40, 547-555. [CrossRef]

53. Li, Y.; Horsman, M.; Wang, B.; Wu, N.; Lan, C.Q. Effects of nitrogen sources on cell growth and lipid accumulation of green alga Neochloris oleoabundans. Appl. Microbiol. Biotechnol. 2008, 81, 629-636. [CrossRef] [PubMed]

54. Ördög, V.; Stirk, W.A.; Bálint, P.; Staden, J.; Lovász, C. Changes in lipid, protein and pigment concentrations in nitrogen-stressed Chlorella minutissima cultures. J. Appl. Phycol. 2012, 24, 907-914. [CrossRef] 